\title{
Progress and Free Will: On the Buddhist Concept of "Time" and Its Possibilities for Modernity
}

\author{
Bart DESSEIN*
}

\begin{abstract}
An even only cursory glance at the way Buddhism is experienced, interpreted, and lived in the contemporary world-both Western and Oriental--reveals Buddhism's multiple "modern faces". This paper does not intend to describe all or even a selected group of these many faces, but attempts to contribute to our understanding of how peculiar developments within Buddhist philosophy have made it possible that such a variety of "Buddhist modernities" could develop. It is shown that it is the peculiar Buddhist interpretation of the concept of time that has provided the basis on which the various modern features of Buddhism could build, because the Buddhist interpretation of time contains an aspect of progress and free will. It is suggested that these two aspects increased the prominence given to the individual adept in the Mahāyāna. The article then claims that it precisely are the ideas of rationality, progress and individualism that are also characteristic for the modern world that contain the possibility for Buddhism to develop its multitude of modern faces.
\end{abstract}

Keywords: time, karmic retribution, knowledge, meditation, Buddhist modernity

\section{Izvleček}

Že bežen pogled na to, kako ljudje v sodobnem svetu (tako na Zahodu kot na Vzhodu) doživljajo, interpretirajo in tolmačijo budizem, razkrije, da so zanj značilni številni »obrazi sodobnosti«. V članku ne bom popisoval vseh ali le izbranih vidikov teh različnih obrazov, temveč bom poskušal osvetliti, kako so specifične spremembe znotraj budistične filozofije omogočile, da je nastalo toliko različnih »budističnih sodobnosti«. Zagovarjal bom trditev, da je specifična budistična interpretacija časa postavila pomembne temelje za razvoj številnih značilnosti sodobnega budizma, saj vsebuje dimenziji napredka in svobodne volje, ki sta postali še posebej pomembni v budizmu mahāyāna. Dokazoval bom, da so za sodobni svet značilne prav ideje o racionalnosti, napredku in individualizmu, ki budizmu dopuščajo, da razvije množico sodobnih obrazov.

Ključne besede: čas, karmična retribucija, vednost, meditacija, budistična sodobnost

Bart DESSEIN, Professor of Chinese Language and Culture,

Ghent University, Belgium.

bart.dessein[at]UGent.be

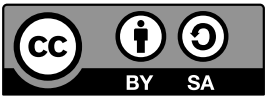




\section{Introduction}

Undertaking an evaluation of Buddhism in contemporary societies is a complex matter, as it immediately raises a series of questions: Which particular society is to be the focus of investigation? Which aspect of contemporaneity is to be discussed? Modernity for a Buddhist lay follower, e.g., will be of a different quality than it is for a monk who lives in the confines of his monastery. These modernities will again have a different meaning than those embraced by, e.g., a female Buddhist devotee who is familiar with the "modern" concepts of gender equality. Given, further, that "(a) sense of time is fundamental to human thought to the extent that the past must be invoked in order to establish any present ideology, even one that involves a discounting of the past. All ideologies are fundamentally descriptions not of a present state, but of a past history" (Kemp 1992,106) each of these Buddhist modernities will itself also be influenced by the particular history of Buddhism in the region under investigation, or by the mutual influence different social and political structures and Buddhism may have had on each other.

As modern life-the contemporary condition bumaine-in India is different from modern life in China, or in Japan, and as also American modernity arguably differs from German modernity or from Slovenian modernity, discussing Buddhism as a bridge between Asia and Europe becomes an even more complex issue. Which Western Buddhism is compared with which Asian version? As Buddhism has also undergone major transformations in the various regions of Asia, and as the concept of "original Buddhism" is merely a 19th century European construct, created in a Protestant, Darwinian, and Romantic context (See Maes 2015, 11-36; Lopez 2008, 5-37, 154-91; McMahan 2008, 7-8). ${ }^{1}$ defining "Western Buddhism" or "modern Buddhism" as against a presumably authentic Indian Buddhism is a futile undertaking. Not only is there no such thing as an "original" Buddhism with which its modern Western versions could be compared, neither is there an overall modern Asian prototypical Buddhism. Contemporaneity in Asia has, in the past two centuries, seen the influences of European colonization, which have changed the political structures that were associated with Buddhism; confrontation with Western religions and ideologies has stimulated Buddhist activism; it has, in some cases, made Buddhists participants in civil war, or has stifled any Buddhist activity; capitalism has changed traditional value-structures; and also such "modern" concepts as democracy, egalitarianism, and secularization have had a great impact on Buddhism. In the

1 This can also be inferred from, e.g., Sir Edwin Arnold's 1879 The Light of Asia, a poem on the life of the Buddha that portrays the Buddha in a way that is akin to Jesus. See Harvey $(2013,420)$. 
contemporary digital age, traditional Buddhist cultures have easily transgressed their regional confines, and a whole new "Buddhist world" has emerged. ${ }^{2}$

And yet, we can rightfully speak of "modern Buddhism", "Western Buddhism", "European Buddhism", "American Buddhism", etc. In the introduction to his work Deutsche Buddhisten. Geschichte und Gemeinschaften, Martin Baumann $(1992,15)$ correctly states that the Europeanization of Buddhism comprises the acceptance of Western cultural elements by Buddhist interpreters and monastic communities, and that despite the fact that this development has changed the face of Buddhism, elements we can easily define as "Buddhist" have been maintained. It is precisely because there is commonality of Buddhist concepts that the "other" can be qualified as "Western", "European", or "American".

It is to one of these commonalities that the following pages are devoted: the concept time. It will be shown that the development in the interpretation of the Buddhist concept time has made it possible for the Buddhist doctrine to have become adaptable to a multitude of simultaneous modernities-be they Asian or European, be they of a moral, ethical, religious, social, or still other nature.

\section{"Sarvam asti": Everything Exists}

Confronted with the vicissitudes of life, human beings have always and everywhere tried to understand their present condition and have tried to give their contemporary life sense and meaning. This intellectual process is intrinsically related to the way a human being perceives time. Time can be interpreted as either having a dependent or independent existence, and as being either finite or infinite. That is, human beings can see themselves as traversing through an either finite or infinite but independently existing time, or they can see time as inherent in themselves. The first position implies that time has an absolute quality, i.e., time does not exist relative to a human being. The disappearance of a human being, i.e. the disappearance of one's personal allotment of time, has no impact on the absolute time that continues to either infinitely or finitely exist. Human beings cannot therefore have a lasting effect on time. The second position implies that time exists relatively to human beings. One's personal allotment of time, that is, the relative time, disappears together with the passing away of a human being. As time exists within oneself, time is finite by definition. ${ }^{3}$

2 For a detailed analysis of all these phenomena: see Harvey (2013, 376-418).

3 In Western philosophy, the absolute concept of time was formulated by Isaac Newton in his Philosophiae Naturalis Principia Mathematica, published in 1687, and the relative concept of time was formulated by Immanuel Kant in the part "Transcendental Aesthetic" of his Critique of Pure Reason, published in 1787. For some further theoretical reflections on the topic: see Li and Dessein $(2015,157-8,172-3)$. 
The Buddhist concept of karman, i.e., the concept that the present lifetime is the retribution (vipa $\bar{k} k a)$ of deeds in a former lifetime, is a particular interpretation of the relationship between discrete factors (dharma), including human beings, and time. While Buddhism inherited the concept of karman from the Indian tradition within which it developed, and while all Buddhists, from the outset, accepted that the dynamics of karman are responsible for their contemporary life and also determine future rebirth, it was especially the Sarvāstivādins, whose development as a distinct philosophical group has been suggested to date back to the 2 nd and 1 st centuries $\mathrm{BCE}^{4}$, who philosophically developed the relation between discrete factors and time, whence their name. ${ }^{5}$ The Sarvāstivādins' (main) claim (vāda) that everything (sarva) exists (asti) is, actually, a claim that the discrete factors exist in three distinct periods of time. This position is logically inferred from the dynamics of karman as expressed in the concept of "conditioned production" (pratityasamutpāda), the workings of causality, whereby a present discrete factor is the result of former causes and is, in its turn, the cause of a future discrete factor. The *Samyuktābhidharmahrdaya, a work written in Gandhāra in the 4th century CE by the Sarvāstivādin Dharmatrāta and which is extant in a Chinese translation by Samghavarman of $434 \mathrm{CE}$, describes this process as follows:

If there were no past and future, then there would be no present period of time; if there were no present period of time, there would also be no conditioned factors (samskrta dharma). That is why there are the three periods of time (trikäla). Do not state that this is wrong. When stating that what is remote is past and that what will exist is future and (that it therefore) does not exist, and that there is only the present, this is not correct. Why? Because there is retribution (vipazka) of action. The World-honored One said: "There is action and there is retribution". It is not the case that action and retribution are both present. When action is present, retribution should be known as future; when retribution is present, action should be known as already past. (T.28.1552, 963b5-12)

We can here recall that the *Samayabhedoparacanacakra, a work attributed to a certain Vasumitra ${ }^{6}$ explains that the name "Hetuvādin" (causalists) is another name

$4 \quad$ Hirakawa $(1974,143)$ suggests the 2nd century BCE; Shizutani (1978, 48 ff.) suggests the 1st century BCE.

5 Bronkhorst $(2011,116-7)$ remarks that "Brahmanical religion allowed various sometimes mutually contradictory points of view with regard to one's future destiny to coexist, and some of the most conservative Brahmins, the Mìmāṃsakas, had no place for the theory of karma right up to the middle of the first millennium $\mathrm{CE}$ and beyond".

6 According to Bareau (1950, 70), this work was compiled between the 3rd and the 1 st centuries BCE and the 1st century CE. Lamotte $(1958,301-2)$ dates Vasumitra 400 years after the Bud- 
for the Sarvāstivādins (T.49.2033, 22c9-10.). Bhavya, a 6th century Mādhyamika (see Bareau 1954, 231-2), explains the causalist principle as follows: "What has been produced (utpanna), what is being produced (utpadyamanna), and what is to be produced (utpattavya) is all supplied with causes (sahetuka)."

This basic description of the concept of dependent origination would, as mentioned above, be accepted by all Buddhist schools. It therefore is indeed likely that it was only later that peculiar philosophical explanations of how the concept of dependent origination technically relates to the concept of time were formulated, and that it especially was the Sarvāstivādins who were responsible for this development.

The above quotations show an intricate connection between the dynamic working of karman (through conditioned production (pratityasamutpāda)) and the time concept (past, present, and future). A logical result of this connection has been that, for the Sarvāstivādins at least, time is none other than the activity of discrete factors. As stated by Kenneth K. Inada (1974, 173): “(E)xperiential events do not take place or flow in time. Rather, it would be more appropriate to say that events flow as time". Time is inherent in the discrete factors that therefore must have a continuous essence (dravya), stretching from the past, over the present, to the future. In this sense, the "temporality" of discrete factors is superimposed on them by a subjective observer. ${ }^{8}$ (See Dhammajoti 2009, 117-8)

The importance of this philosophical development notwithstanding, the technical question of precisely how karmic activity and time are connected, i.e., the question how precisely time manifests itself in the discrete factors, became heavily debated between the Kāśmīri Vaibhāṣikas and the non-Vaibhāṣika Sarvāstivāda sugroups of Bactria and Gandhāra. As just mentioned, the "temporality" of discrete factors is superimposed on the latter by a subjective observer. That is to say, an observer sees discrete factors that have a continuous essence coming into existence, after which their continuance in the present is observed, as well as their disappearance in time once their allotted period of time has passed. In Buddhist vocabulary,

dha's parinirvāna. Masuda $(1925,8)$ situates Vasumitra in the 1st century CE. Cousins (1991, 28) proposes a 1 st to 4 th century $\mathrm{CE}$ date for Vasumitra. There are three Chinese versions of this text: Yibuzong lun lun (T.49.2031), Shiba bu lun (T.49.2032), and Buzbiyi lun (T.49.2033). On the dates of these three versions: see Masuda $(1925,5-6)$, Lamotte $(1958,302)$ and Wang $(1994$, 171, 175-6).

7 For Bhavya's explanation: see Rockhill (1884, 182), Walleser (1927, 78-9), Bareau (1956, 168).

8 Dux $(1989,37)$ states that "When we say 'now', we do not only denote the actual moment of our own existence; 'now' is the expression of the situation of the universe in the logical second of its most advanced duration, the moment of its transition in the dynamic organization that encompasses everything and everyone that is simultaneous with ourselves". 
this is expressed in the concept of the "characteristic marks of the conditioned" (samskrta lakșana): birth (utpäda), change in continuance (sthityanyathätva), and passing away (ryaya). ${ }^{9}$

Between the Vaibhāșikas and the non-Vaibhāṣikas, discussion arose whether or not these "characteristic marks of the conditioned" exist as discrete factors themselves. This discussion had major ramifications for the way the functioning of time was perceived. From the [ ${ }^{*}$ Abhidharmamahā] vibhāṣā [śāstra], the major work of the Kāśmīri Vaibhāșikas (dated roughly somewhere around the end of the 1 st to the end of the 2 nd century $\mathrm{CE})^{10}$ we know that the Vaibhāsikas saw the characteristic marks as discrete factors in their own right. ${ }^{11}$ If the characteristic marks exist as discrete factors in their own right, the question is then how they relate to the factor with respect to which they, as discrete factors, have a function, for such a relation must exist. If there were no relation between the characteristic marks and the specific discrete factors they characterize, all factors would arise or disappear simultaneously because the presence of the characteristic marks as discrete factors is true with respect to all possible discrete entities. If, however, the characteristic marks of the conditioned do not exist as discrete entities but equally exist with respect to a specific discrete factor, which is the position held by the non-Vaibhāṣika Sarvāstivādins, the question then is why the characteristic marks birth, change in continuance, and passing away do not function simultaneously with respect to the discrete factor they characterize, that is, why does a discrete factor not disappear at the very moment it arises? The non-Vaibhāșikas' answer to the above question can be read in Vasubandhu's Abbidharmakośa:

9 Sinha $(1983,85)$ remarks that "It is not the reality of past, present, and future as three points of time that is posited by Mahävibhāșä; rather, it is the reality of things or dharmas as past, present, and future that is admitted here". For a detailed study of this problem: see Dessein (2007) and Dessein (2011).

10 On the different traditions on the date of the compilation of this work: see Nakamura $(1996,107)$ and Willemen, Dessein and Cox $(1998,119,231-2)$. The Chinese version of this work was done by Xuanzang between 656 and 659 CE. (See T.55.2154, 557a18-19 and 320c12-16)

11 This implies that these "primary" characteristic marks (mülalaksana) must be, in turn, characterized by further characteristic marks, the so-called secondary marks (anulakșana). It is clear that this standpoint leads to an infinite regression, as these secondary marks should logically be discrete factors in their own right and have further characteristic marks as well. When their opponents pointed to this infinite regress, the Vaibhāṣikas answered that the primary birth gives rise to the actual factor, and further leads to continuance, change and passing away, and that it also induces birth of birth, continuance of continuance, change of change, and passing away of passing away. Birth of birth, they claimed, only gives rise to primary birth. The next question for the Vaibhāșikas obviously then was to explain how the birth of birth can bring forth birth when it itself arises through birth. (See T.27.1545, 200c15-28) 
The World-honored One (...) manifested that it is the essence of a stream of conditioned force that is (designated as) conditioned and as having the nature of having arisen through conditions. (...) He did not manifest that all three characteristic marks are present in one (separate) kșaṇa (instant) of a conditioned force. ${ }^{12}$ (T.29.1558, 27c2-4)

When the characteristic marks are absent in one separate instant, but are present in succession, it is logically "birth" that brings a discrete factor into existence. "Birth" is that instant in the subjectively perceived stream of successive moments in which a discrete factor acquires its essence (dravya). This acquisition of the essence is the result of conditioned arising, that is, of the combination of causes (betu) and conditions (pratyaya) through former karmic activity. For the Vaibhāșikas, this position is untenable because when a factor acquires its essence through "birth", then a change in characteristic marks would imply a change in essence. A given discrete factor would become a different discrete factor along with the succession of the characteristic marks birth, continuance, change, and passing away. They therefore differentiated a latent "capability" (sämarthya) and an active state (käritra) of the characteristic marks. This solution is related to their acknowledgement that characteristic marks are discrete factors themselves. Any single characteristic mark has the ability to change from a latent state to an active state while continuously existing as an independent discrete factor, simultaneously with the discrete factor on which they have an effect (See T.27:1545, 200a9-b5, 393a15-16). A logical result of this interpretation is that it is no longer the characteristic mark birth that brings a discrete factor into existence, but the "becoming active" of birth. A next question to be solved was the following: When the characteristic marks exist as discrete factors themselves, how then does birth become active with respect to a particular discrete factor, without thereby eliminating the relation between characteristic marks and the discrete factor on which they have an effect, i.e., avoiding the possibility that all discrete factors arise and disappear simultaneously? The Vaibhāșikas found the solution to this problem in the concept of conditioned production: Birth needs a particular assemblage of causes and conditions to become active (See T.29:1562, 409a28-b1 and 409b11-13). These causes and conditions are a karmic continuation with respect to a particular discrete factor.

That karmic activity in the present lifetime will, through the principle of conditioned production, have its effect on a future life, brings us to the peculiar position that the Buddhist cycle of rebirth (samsāra) - a cyclic time concept-contains an aspect of progress: each beginning of a new cycle through karmic retribution is not a return

12 The lifetime of Vasubandhu remains on object of scholarly discussion, with arguments for either a 4 th century or a 5 th century lifetime. 
to a "timeless origin". ${ }^{13}$ Karmic "progress", it should be noted, is also not determinist. For most Buddhist schools, the result of karman is morally indeterminate (avyākrta), which means that karmic retribution does not determine fortune and misfortune: the Buddhist cycle of rebirth leaves space for free decision (See Halbfass 2000, 116-8; Bayer 2010, 50-51). Günter Dux $(1989,236)$ remarked that, as a rule, life is "loaded" and returns back to the origin. The origin, however, is twofold: the origin that is timeless and the origin that adjusts to becoming. As long as the soul is loaded, it cannot return to the timeless origin, but only to the origin of becoming. Only those who have attained wisdom that is free from any bond to the world can return to the timeless origin. In this process, one does not destroy time, but liberates oneself from time. Applying this to Buddhism, while the earlier, non-Vaibhạsika position saw time as inherent in the discrete factors, which implies that time is relative and stops with the passing away of an individual human being, thus making a return to a "timeless origin" impossible, the Vaibhāșikas' distinction between a passive state and an active state of the characteristic marks created the following "eschatological" possibility: when a Buddhist adept, through pursuing the middle mode of progress (madhyama pratipad), attains Nirvanna, their relative time may have stopped, but the absolute time will continue to latently exist. They therefore can return to the "timeless origin". With this time perspective, Buddhism, one could claim, stands in between a strict cyclical concept of time and a linear one that was, for Europe, developed as a result of the Jewish-Christian eschatology, and was introduced by Augustinus (354-430). ${ }^{14}$ I will return to this when discussing Buddhism in the contemporary European world.

\section{The "Powers of Cognition" and the Idea of Individual Progress}

Above, we have stated that the dynamics of dependent origination leave the place open for free will: whether or not a human being follows the Buddhist path of liberation that will, in the end, enable him to return to the "timeless origin", is his free decision. ${ }^{15}$ It is, moreover, because the cyclic time concept of Buddhism contains an idea of progress that it is possible to gradually shake off all bonds to the world

13 This time concept differs from the traditional Chinese cyclic time concept that lacks this aspect of progress. See Bauer (2006, 37-8).

14 Taking the birth of Christ as the focal point of history, Augustinus' linear time model was divided into three time periods: the period from Adam to Moses, the period from Moses to the birth of Christ, and the period from Christ to the end of the world. The resurrection of Christ is the endpoint of this linear interpretation of time. For the development of the time concept in Europe see Dux (1989, 327-31).

15 Also in this respect, Buddhism differs from the Christian doctrine. For Christianity, the fact that all human beings are created by God, makes them part of a divine plan. See Göller and Mittag (2008, 28,31 , who characterize Augustinus's view of history as the transformation of the history of a clan, people, or tribe into the history of mankind. 
and liberate oneself from time. The importance of these concepts is visible in the description of the Buddhist path to liberation as it is presented in the Sarvāstivāda philosophical works. While progressing on the path to liberation, the practitioner gains and practices different forms of knowledge and forms of meditative attainment. On the path to liberation, there thus is an interplay between knowledge and meditative attainment, i.e., between the cognitive and the meditative. ${ }^{16}$

The path to liberation consists of a "path of vision" (darsanamärga) and a "path of spiritual practice" (bhãvanāmārga). The distinction between these two kinds of path is based on the way passions (anusaya) are annihilated, i.e., through vision and repeated spiritual practice, respectively. There is a basic set of ten passions that are simultaneously linked to the three Buddhist realms of existence (the sensual realm (kämadhātu), the realm of form (rüpadhātu), and the realm of formlessness (ārūpyadhātu)) and that are to be partly annihilated through vision (darsanaprahätavya) of the four noble truths and partly through repeated spiritual practice (bhävanäprahätavya). This means that for the final destruction of all these passions, one has to apply vision and repeated spiritual practice of all four truths, and throughout the three realms of existence. As the śravaka progresses in this pursuit, he attains the ten kinds of knowledge as follows: When he initially enters the path to liberation, he first develops patience regarding the truth of suffering (dubkhasatya) in relation to those passions that belong to the realm of sensual passion. This moment is called "patience regarding the truth with respect to suffering" (dubkhe dharmaksānti). In this moment, what is destroyed is that particular part of the ten passions that belongs to the realm of sensual passion and that is to be destroyed by vision of the truth of suffering. As the srävaka, in this moment, is not yet free from desire, he acquires conventional knowledge (samvrtijñana). This moment is followed by a second moment in which the same truth is fully understood. This moment is called "knowledge of the truth with respect to suffering" (dub̧khe dharmajñanna). In this moment, the śrävaka makes sure that the part of the passions that was annihilated in the previous moment does not reoccur.

The śärvaka now takes possession of two more types of knowledge: knowledge of the doctrine (dharmajñäna) and knowledge of suffering (dubkhajñanna). This second moment is followed by a third moment, which is related to that part of the passions that is to be destroyed by vision of the truth of suffering and belongs to the higher two realms. This moment is called "subsequent patience regarding the truth with respect to suffering" (dub̧khe 'nvayaksānti). The final destruction of this part of the passions, i.e., the certitude that also this part of the passions will not reoccur, is called "subsequent

16 For a discussion on the different theories that have been formulated concerning the relation between knowledge and meditative attainment see Cox (1992, 65-66 and 83-86). 
knowledge regarding the truth with respect to suffering" (dubkbe 'nvayajñana). In this fourth moment, the śravaka also takes possession of subsequent knowledge (anvayajñana). As there are four truths, there are sixteen moments in this "path of vision" (darsanamärga). In the sixth moment, knowledge of the origin (samudayajñana) is further acquired; in the tenth moment, knowledge of cessation (nirodhajñäna); and in the fourteenth moment, knowledge of the path (märgajñanna).

Having reached the sixteenth moment on the path of vision, the srärvaka enters the stream towards liberation. He now has to subdue that part of the same passions that is to be annihilated through repeated spiritual practice. While doing so, he continues cultivating the seven kinds of knowledge he has already attained on the path of vision. Once the śrävaka has attained the fruit of nonreturning (anaggamyaphala), i.e., the last of the noble fruits (śramanyaphala) before attaining arhat-ship, he obtains the knowledge of the thoughts of others (paracittajñana), as he is now completely freed from the realm of sensual passion. When the śävaka has accomplished his task of completely destroying all passions, he obtains the last two kinds of knowledge: knowledge of destruction (ksayajñana), i.e., knowing that all passions have been destroyed, and knowledge of nonorigination (anutpädajñāna), i.e., knowing that one is no longer subject to rebirth. ${ }^{17}$ Because with the obtainment of the knowledge of destruction and of the knowledge of nonorigination the śrävaka enters Nirvāna, he equals the Tathāgata. These two kinds of knowledge therefore pertain to the Tathāgata only (T.28.1550, 821b24-c2).

Table 1: The obtainment of knowledge on the path to liberation

\begin{tabular}{|c|c|c|}
\hline $\begin{array}{l}\text { path of vision } \\
(\text { darśanamäro } a)\end{array}$ & & \\
\hline & moment 1 & conventional knowledge (samvrtijñāna) \\
\hline & moment 2 & $\begin{array}{l}\text { knowledge of the doctrine (dharmajñāna) } \\
\text { knowledge of suffering (dubkhajñāna) }\end{array}$ \\
\hline & moment 4 & subsequent knowledge (anvayajñāna) \\
\hline & moment 6 & knowledge of the origin (samudayajñana) \\
\hline & moment 10 & knowledge of cessation (nirodhajñana) \\
\hline & moment 14 & knowledge of the path (märgajũāna) \\
\hline $\begin{array}{l}\text { path of spiritual prac- } \\
\text { tice (bhävanāmärga) }\end{array}$ & & \\
\hline & & $\begin{array}{l}\text { knowledge of the thoughts of others (paracittajñāna) } \\
\text { knowledge of destruction (kșayajñāna) } \\
\text { knowledge of nonorigination (anutpādaiñana) }\end{array}$ \\
\hline
\end{tabular}

17 The earliest description of this path is found in Dharmaśreșthin's *Abhidharmahrdaya, a non-Vaibhāṣika Sarvāstivāda Abhidharma text that has to be dated around the beginning of the Common Era. (See T.28.1550, 820b25-c18) Notice that it might be that a śävaka, actually, is already free from desire when entering the path of vision. In that case, he possesses the knowledge of the thoughts of others from the outset. 
The idea of individual progress that is evident from the above is also visible in the related concept of the so-called "powers of cognition" (jñannabala). A list of ten powers of cognition already figured in the Samyuktägama as a part of a discussion on the difference between the fully awakened (samyaksambuddha) Tathāgata and the arbat who is liberated through wisdom (prajñavimukta). Of this series of ten powers of cognition, two are particularly important in light of the development of the interpretation of time provided in the previous section: the "power of the cognition of one's former abodes or existences" (pürvanivāsajñannabala), i.e., the Buddha's power to know all his and all other beings' previous existences; and the "power of the cognition of death and rebirth of sentient beings" (cyutyupapädajñanabala), i.e., the Buddha's power to see with his divine eye (divyacaksus) the place of death and rebirth of all beings. These two powers of cognition are developed in a trance state (dhyāna) and have a material form as cognitive object. ${ }^{18}$

While the possession of these powers of cognition is, according to the Samyuktāgama, (i.e., according to Śrāvakayāna Buddhism) (T.2.99, 186c17-187b5), ${ }^{19}$ only possible for the Tathāgata, with the development of the Mahāyāna, they were thought not to be unique for the historical Buddha, but also to be obtained by the Buddhist adept. This can be inferred from Dharmaśreșthin's *Abhidharmabrdaya in which the powers of cognition are discussed with respect to their

18 The other eight are: the power of the cognition of the possible and impossible (sthānästhānajnānabala), i.e., the Buddha's power to know all factors, their causes and conditions (hetupratyaya), and the mechanism of their fruits of retribution (vipäkaphalaniyāma); the power of the cognition of retribution of action (karmavipäkajñanabala), i.e., the power to know the sphere of action (karmasthā$n a)$ of all kinds of actions of the past, present, and future; the power of the cognition of trances, liberations, meditative attainments and samādhis (dhyānavimoksasamādhisamäpattijnāanabala), i.e., the power to know all these auxiliary factors of the path to liberation; the power of the cognition of higher and lower faculties (indriyaparäparajñanabala), i.e., the power to know the moral faculties of all beings; the power of the cognition of resolve (nānädbimuktijñanabala), i.e., the power to know the purity (prasāda) and the inclinations (ruci) of all beings; the power of the cognition of dispositions (nānädhätujñanabala), i.e., the power to know acquired dispositions of all beings in all spheres of existence; the power of the cognition of the courses (sarvatragàminipratipajjñanabala), i.e., the power to know which way leads to which destination; and the power of the cognition of the destruction of impure influence (äsravaksayajñänabala), i.e., the power to know the destruction of impure influence, the nature of impure influence and the mindset of himself and of all beings.

19 An abridged version of the same is found in T.2.99, 189a7-13. For an extensive treatment of the ten powers of cognition: See Lamotte (1970, III: 1524-1563). Sanskrit versions of the Dasabalasütra are quoted in the Sphuțarthäbhidharmakosavyākhyā: Wogihara (1971, 614: 1.14-642,1.26), attesting many variants. For fragments of manuscripts: see Lamotte (1970, III: 1506). For other variants: see Lamotte (1970, III: 1509-1510). These ten powers of cognition are also enumerated in the Ekottaraggama (T.2.125, 776b16-c20), which continues with listing four kinds of confidence (vaisäradya), equally possessed by the Tathāgata (T.2.125, 776c20-777a5). These two series also figure in the "Greater Discourse on the Lion's Roar" of the Majjbimanikaya (MN I: Trenckner $(1988,71)$, Horner (1954, 95-97). 
mutual relation, and with respect to their relation with the ten kinds of knowledge (jñana) a śävaka takes possession of when progressing on the path to liberation, a treatment that suggests that the śävaka also has part in them. ${ }^{20}$ This also explains why the *Abhidharmahrdaya and Dharmatrāta's "Samyuktäbhidharmahrdaya deal with this topic in the chapter "Knowledge". ${ }^{21}$ The order in which the ten powers of cognition are discussed in these works is also the order we find in the Samyuktāgama, and is the order as it became standardized in the Sarvāstivāda literature. ${ }^{22}$ According to the *Abhidharmahrdaya, the first power of cognition comprises the ten forms of knowledge a śrävaka develops (T.28.1550, 820b26-c18). For the other nine powers of cognition, Dharmaśreșțin only states that they are different from the first power of cognition as to the number of knowledges they comprise (T.28.1550, 822c29-823a14). ${ }^{23}$ Dharmatrāta's *Samyuktäbhidharmahrdaya, a work that is heavily influenced by Vaibhāșika viewpoints, further informs us that the power of cognition of the former abodes or existences comprises one knowledge: the knowledge of former existences, which is a type of conventional knowledge, and that the same is true for the power of cognition of birth and death (T.28.1552, 922a15-16 and 922b2-3 resp). ${ }^{24}$ The possibility to know previous existences obviously relates to the progressive aspect we delineated above.

Dharmatrāta's *Samyuktābhidharmahrdaya as well as the *Abhidharmamahävibhāșāsáastra further list the ten powers of cognition together with a corresponding series comprising four types of confidence (vaisāaradya), great compassion (mahäkaruña), and three kinds of mindfulness (smrtyupasthāna), thus forming a list of eighteen factors. This list is called the "eighteen unique factors (āvenikadharma) of a Buddha" (T.28.1552, 922c16-18; T.27.1545, 85a26-27, $156 \mathrm{c} 16$ ff., 624a14-15, 735c16-18). The Sarvāstivāda Abhidharma literature thus appears to have developed a series of "eighteen unique factors of a Buddha",

20 The Chinese version of this text was done by Samghadeva and Huiyuan in 391 CE. See T.28.1550, 809a5-7; T.50.2059, 357c23-361b13; T.55.2145, 72c29, 99c17-18. See also Willemen (1975, xxxii, note \# 40). For a detailed study of this concept: see Dessein (2010).

21 The *Abhidharmahrdaya first discusses the elements of existence (dharma), the formations (samskära) that are responsible for the process of causality, and the actual actions (karman) that beings commit. After this initial exposition, the author outlines the passions (anusaya) that are the fundaments of the actions committed, and the phases of nobility (ärya) a śrävaka goes through to eventually reach arhat-ship. These two chapters can be considered as the core chapters of the text as the passions are the fundaments of rebirth, and the phases of nobility form the antipode to samsära. In the chapters on knowledge (jñ̄na) and concentration (samädbi), the qualities attained while progressing on the path to liberation are addressed. Note that also the sutra literature urged the bhiksus to develop the powers of cognition. (See T.2.125, 777a12-13)

22 On the likely Sarvāstivāda affiliation of the Samyuktāgama: see Waldschmidt (1980,136, 139,148).

23 See also Willemen (1975, 101-4), Armelin (1978, 152-3).

24 See also de La Vallée Poussin (1971, V: 71). 
of which it is explicitly stated that they do not to belong to the srävaka or to the pratyekabuddha (T.27.1545, 158a4-11).

Table 2: The relation between the powers of cognition and the ten kinds of knowledge

\begin{tabular}{|c|c|}
\hline Power of cognition & Ten kinds of knowledge \\
\hline $\begin{array}{l}\text { power of the cognition of the possible } \\
\text { and impossible (sthānāsthānajñānabala), }\end{array}$ & 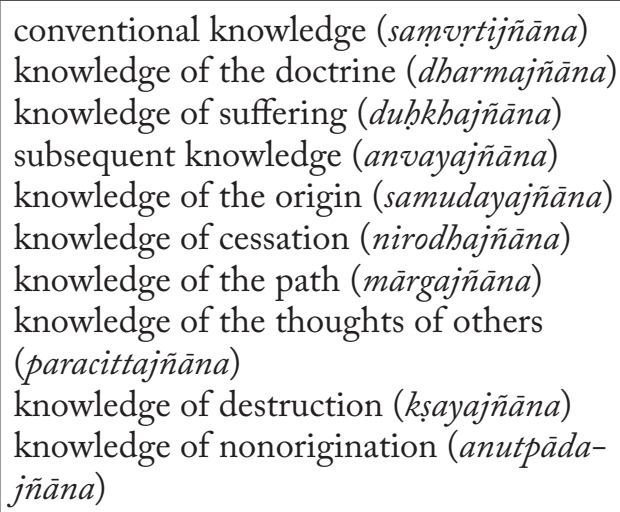 \\
\hline $\begin{array}{l}\text { power of the cognition of one's former } \\
\text { abodes or existences (pürvaniväsajñänabala) }\end{array}$ & conventional knowledge (samvrtijñāna) \\
\hline $\begin{array}{l}\text { power of the cognition of death and } \\
\text { rebirth of sentient beings (cyutyupapäda- } \\
\text { jñanabala) }\end{array}$ & conventional knowledge (samvrtijñāna) \\
\hline
\end{tabular}

This explicit statement in the Abhidharmamahävibhäșāsástra notwithstanding, we have learnt from the above that when a śravaka progresses on the path to liberation, he takes possession of ten types of knowledge, the last two of which consists of his transformation from being a śävaka to being Buddha-like. Along with taking possession of these ten types of knowledge, the śrarvaka also develops powers of cognition, the last two of which are types of conventional knowledge that enable him to look back on previous existences. The fact that a śäraka becomes Buddha-like, and that he takes possession of powers of cognition which in Sutra literature were stated to be unique for the Buddha, conflates at least some qualities of a śävaka and a Buddha.

In circumstances where, one the one hand, some characteristics were ascribed to the Buddha only, and, on the other hand, no difference seems to have been made between some qualities of the Buddha and of the liberated srävaka-both were called "arhat" (See Bareau 1957)25_discussion arose as to what precisely the difference between an arhat and a buddha consisted of, and the infallibility

25 See also Jaini (1992) and Bronkhorst (2000, 127-8). 
of an arhat became questioned. As a result, some Buddhists no longer regarded arhat-ship as the ultimate goal of religious praxis, but they chose to strive for bodhisattva-ship, thus aspiring to become a Buddha—or, at least, to possess the same qualities a Buddha has. The Mahāyāna acceptance of a simultaneous existence of multiple Buddhist universes, each with its own Buddha, naturally further enhanced this possibility.

The development of the concept of the bodbisattvayanna thus radically changed the path of cultivation. Nāgārjuna's Mahäprajñāpāramitāsāastra, a commentary on the *Pañcavimśatisāhasrikā, an expanded version of the Prajñäpāramitāsūtra, gives us detailed information on this new path. ${ }^{26}$ Addressing the issue of the powers of cognition, the text states: "(Moreover,) Śāriputra, the Bodhisattva-Mahāsattva who wants to understand the ten powers of cognition (jñanabala), (...), should develop prajūāpāramitā (T.25.1509, 235a28-b1)."27

In the subsequent explanation, it is stated that the qualities just enumerated are peculiar for the Buddha, and that a bodhisattva should first exercise the qualities of a śärvaka in order to convince the śärakas and the pratyekabuddhas to turn to the Mahāyāna (T.25.1509, 235b1-c3). This statement clearly depicts the śra vakayāna as a preparatory vehicle for the bodhisattvayanna, as it is further stated that, having acquired the qualities of the srävaka, the bodbisattva is desirous of obtaining or desirous of knowing the qualities that particularly pertain to the Buddha. To attain this aim, he must cultivate prajñāpanramitā (T.25.1509, 235c3-21, 236b10-12, b21-22).

The *Pañcavimisatisāhasrikà also gives evidence that a bodhisattva must first develop the qualities of a śrävaka. According to this work, a bodbisattva has twenty-one characteristic marks, seventeen of which he shares with a srävaka and four of which he shares with the Buddha (See Conze 1961,203-12). That the bodbisattva possesses characteristics that partly belong to a srärvaka and partly to the Buddha may be explained by the following: contrary to the Buddha, a bodhisattva delays his eventual entry into nirvaña and remains in samsāra with the purpose of consecrating himself for the well-being of worldlings (prthagjana) as long as possible. First practicing the srävakayana may enable him to help the adherents of this vehicle shift to the Mahāyāna.

26 The 2nd century text was translated into Chinese as Da zhidu lun (T.25.1509) by Kumārajīva between 402-6. (See T.25.1509, 756c9-18; T.55.2145, 75b10-18) Kumārajīva translated the Pañcavimśatisāhasrikà simultaneously. See also Lamotte (1970, III: v-vi, xlv-1). The short recension is the Asțasāhasrikā Prajñāpāramitā. The long recensions are the Aștsadaśasāhasrikāa, the Pañcavimsatisāhasrikā and the șatasāhasrikā.

See also T.8.222, 149b8-9. 
That the bodhisattva indeed can obtain the powers of cognition is affirmed in the Mahāprajñāpāramitāsáastra, as follows:

The bodhisattvas have not yet obtained the ten powers of cognition, and the srävaka and the pratyekabuddha are unable to obtain them. So why are they mentioned now? Answer: Although a śrävaka is unable to attain them, when he hears about the quality of these ten powers of cognition, he thinks: "The Buddha has such great qualities," and he rejoices himself in saying: "We have obtained great gains and abundant good." Thanks to the purity of their faith, they enter the path of destruction of suffering. When the bodbisattvas hear about [the ten powers of cognition], they diligently cultivate the path of the bodhisattva, and at will obtain such ten powers of cognition and other fruits of great quality (T.25.1509, 236a14-19).

and:

Because the Buddha has such qualities, therefore one should think about the Buddha. The Bodhisattva-Mahāsattva therefore wants to obtain the ten powers of cognition, the four types of confidence and the eighteen unique factors of the Buddha, and he thus should study prajñāparamitā (T.25.1509, 236b9-12).

The difference between a bodhisattva and the Buddha is also visible in the following passage of the Mahāprajñāparamitāsästra: When the question is raised why, with thirty-six attributes of the Buddha (ten powers of cognition, four types of confidence, three kinds of recollection, great compassion and eighteen unique factors), only eighteen are said to be unique (avenika), the answer given is that the śävakas and the pratyekabuddhas possess part of the first eighteen, but have no part in the second series of eighteen (T.25.1509,247b19-22). This is also affirmed in the following:

The arhat, pratyekabuddha and bodhisattva (in some way take part in the ten powers of cognition that Kātyāyanīputra took for attribute unique for the Buddha): they too know the possible and impossible, have the power of cognition of retribution, have the (power of) cognition of dhyana and samāpatti and so up to the (power of) cognition of the extinction of impure influence (T.25.1509, 255b25-c22).

As according to the Mahāyāna arhat-ship is no longer the ultimate goal of religious praxis, acquiring the qualities that before were ascribed to the fully enlightened arbat-among which are the ten powers of cognition-is not the end of the 
religious path. Having attained this stage, the bodhisattva must still progress on to the further stages of the bodhisattva (bodhisattvabhümi).

That a bodhisattva was not thought of as completely identical to the Buddha is evident from the fact that the Mahāyāna sütras came to develop separate lists of characteristics for a bodhisattva and the Buddha. The newly developed list of factors that are unique for the Buddha is of a non-canonical origin, however, and is adopted in the Mahāyāna texts.

To sum up: while the sütra literature differentiated ten powers of cognition as exclusive attributes of the Tathāgata, the *Abhidharmamahāvibhāṣāsāstra and the Sarvāstivāda texts that postdate this text add a series of other elements to these ten, and call them the "unique factors of the Buddha". With the rise of the bodhisattvayana, the religious career of the adept drastically changed. According to the Mahäprajñäpäramitā literature, the bodhisattva first had to develop the qualities that also a srävaka and a pratyekabuddha possess, and then has to, through exercising prajñāpa aramitā, also develop the qualities of a Buddha. This explains why early lists of attributes of a bodbisattva contain some qualities that are peculiar for a śärvaka and some that belong to the Tathāgata. Gradually, however, separate lists of unique factors of a bodhisattva and unique factors of the Buddha were developed. This lead to a new, non-canonical, list of eighteen unique factors of the Buddha. The ten powers of cognition no longer figure in this new list, as they became interpreted as also belonging to arhat-ship.

\section{Progress, Free Will, and Buddhist Modernity}

It is clear from the above that the accentuation of an individual's free will, the notion of progress, and the accentuation of both knowledge and meditative attainment in the Buddhist path to liberation are elements that have the potential to fuse with European concepts of "modernity". Before this could actually happen, however, also the European interpretation of the concept time had to undergo fundamental developments. A first such major shift in the way time was perceived in Europe was brought about by the Christian scholastic thinking. After the establishment of history writing in ancient Greece in the 5th century $\mathrm{BCE}$ had deviated the attention from the realm of the sacred, the mythical and the mythological, and redirected it to the profane world (see Göllar and Mittag 2008,17), ${ }^{28}$ Augustinus (354-430) again rendered life on earth untrue

28 Eliade $(1986,97)$ remarks that archaic time concepts are characterized by an annihilation of concrete time, i.e., an anti-historical tendency, the refusal to preserve a memory of the past. This, so he claims, is a refusal of archaic man to perceive himself as a historical being. 
and without value. According to the Christian doctrine, humans are alienated from themselves and will only return to themselves in the transcendent empire of God. Profane life is not meaningful an sich, but is only meaningful in its transcendental function. Another important aspect of the Christian faith is its universal claim: all human beings are created by God and therefore do not merely have the potential to turn to God, but are even summoned to take part in the divine plan to become part of the ecclesiastical community (See Göller and Mittag 2008, 25-31).

A second major shift was brought about starting from the middle of the 15th century, when the development of the physical sciences in the age of Humanism and Renaissance revealed that both time and space are endless. This not only challenged the Augustinian view, but also reinterpreted the role of human beings: they became individual actors in an endless time and space, and personal freedom was seen as a prerequisite for human beings to be able to act individually and creatively (See Casirer 1927, 46).

In the previous sections, we have outlined that, in Buddhism, the cyclic time concept entails an aspect of progress, and that, with the development of the Mahāyāna, human beings-srävakas - were thought to be able to partake in part of the qualities of the Buddha, in this encouraged by the simultaneous existence of multiple universes and Buddhas. Given, further, that the decision to pursue the path towards Buddha-hood is based on a human being's free will, it may therefore be no surprise that the 18th century Europe's appreciation of Buddhism is based on the Buddhist doctrine's rationality. ${ }^{29}$ As Peter Harvey stated $(2013,419)$ :

Like Christianity, Buddhism had a noble ethical system, but it appeared to be a religion of self-help, not dependent on God or priests. Like science, it seemed to be based on experience, saw the universe as ruled by law, and did not regard humans and animals as radically distinct.

Into the 1960s, Buddhism in Europe remained primarily focused on the rationality of the Buddhist doctrine, and its preoccupation with intellect and experience; cultic activities were often seen as a degeneration of the "original" Buddhism (Baumann 1992, 17).

29 In the world of philosophy, Buddhism reached the West through such thinkers as Arthur Schopenhauer (1788-1860) who, however, conflated concepts of Buddhism and Hinduism. In the field of literature, we can mention, e.g., Hermann Hesse's 1922 Siddhartha and the poems by Allen Ginsberg and Gary Snyder (see Tonkinson 1995), and in the field of psycho-analysis, Carl Jung is known to have been influenced by Buddhist practices. (See Harvey 2013, 419-20) For the latter: see Fromm, Suzuki, and De Mortino (1963). 
As we have outlined above, the Buddhist path to liberation was from the outset characterized by an intricate interplay between knowledge and meditative attainment. That is, engaging in meditative practices does not necessarily infringe on modern man's claim to rationality-actually, the very reverse is true. This may be one element in explaining the popularity of a variety of forms of meditative practices in modern Europe that became prominent in the 1970s (Baumann 1992,17). Peter Harvey continues his description of the appreciation of Buddhism in Europe as follows (2013, 419): "Yet for those with a taste for mysticism, such as those touched by the Romantic movement, it offered more than science."

Since the 1970s, Buddhist modernity in Europe has also seen an increase in Buddhist groups, organizations, and temples that define themselves as Vajrayāna, with, judging from the internet World Buddhist Directory, $44.7 \%$ of the Buddhist groups, centers, monasteries/temples, and organizations in 2010 defining themselves as "Vajrayāna", followed by those of "Mahāyāna" affiliation (36.2 \%), "Theravāda" (11.7 \%), and "Non-sectarian/Mixed" affiliation (7.2 \%). ${ }^{30}$

That Buddhism also serves an individual "modern" agenda may be evident from a glance at the table of contents of Damien Keown's Contemporary Buddhist Ethics (2000) where we find such topics listed as Buddhism and Ecology, Buddhism and Human Rights, Buddhism and Abortion, etc.

Also, in Asia, the coming in of the modern world has changed the face of Buddhism. Discussing Buddhism in Sri Lanka, Richard Gombrich and Gananath Obeyesekere $(1988,126)$ suggested that what they call "Protestant Buddhism" both protested against European colonization and Christian missionization, a process in which emphasis is put on an individual's seeking for their ultimate goal without intermediaries. "Under the influence of Protestantism", they claim, "Religion is privatized and internalized: the truly significant is not what takes place at a public celebration or in ritual, but what happens inside one's own mind or soul". ${ }^{31}$ This development is indeed similar to the advent of Protestantism in Europe that, in its critique of Catholicism, advocated that trust in men could endanger the soul, and provided the individual with a direct access to God (Weber 1951,241).

Discussing contemporary China, Goossaert and Palmer $(2011,304)$ claimed that:

At a basic level, then, the emergence of religious modernity can be said to be characterized by a shift in the relative importance of preexisting

30 For a detailed overview: see Harvey (2013, 451-6).

31 See also McMahan $(2008,7)$. 
forms of Chinese religiosity, from the ascriptive communal cults employing religious specialists to voluntary, congregational, and body-cultivational styles.(...) Another point of continuity - which is also the defining "modern" characteristic of most of these movements-is their conscious identification with tradition, in relation to, though not necessarily in opposition to, a modern secularist culture in which religion is constantly obliged to justify itself, often resorting to modernist or scientific arguments. The traditions thus formulated can be considered "reinvented" in the sense that they create new compositions out of selected elements of tradition-elements often selected for their perceived compatibility with modern, secular values.

From the philosophical developments outlined above, it may be clear that such a "reinvention" of tradition permeates the whole Buddhist history.

\section{Conclusion}

Buddhist doctrine has, from the outset, seen an intricate connection between the dynamic process of karman that operates through conditioned production, and time. It was the Sarvāstivādins who tried to explain precisely how these are technically related. While the earlier non-Vaibhāṣika Sarvāstivādins saw time as inherent in the discrete factors themselves, the Vaibhāṣika Sarvāstivādins regarded discrete factors and time each to have an independent reality. They developed the concept of a relative time, i.e., time as it regards one particular discrete factor, and an absolute time that, once a human being has returned to a "timeless origin" preserves a latent existence. This strengthened a human being's position as a creative actor with respect to their particular relative time. For the further development of Buddhism, the importance of this interpretation was that the notion of "individual progress" was strengthened, albeit within a fundamentally cyclic concept of time. The Buddhist time concept thus came to hold a position within a strict cyclic time concept and a strict linear concept. The philosophical value of this development was that Buddhism more clearly became neither fatalistic nor determinist-it became "modern". The accentuation of an individual's free will, the notion of progress, and the accentuation of both knowledge and meditative attainment in the Buddhist path to liberation are elements that could fuse with European concepts of "modernity" and may, therefore, be helpful in trying to explain the possibility of Buddhist modernity. 


\section{Bibliography}

Armelin, Indumati, trans. 1978. Le Coeur de la loi suprême. Traité de Fa-cheng. Abhidharmahrdayaśästra de Dharmaśrī. Paris: Librairie Orientaliste Paul Geuthner.

Bareau, André. 1950. "Les origines du Śāriputrābhidharmaśāstra." Le Muséon $63(1 / 2): 69-95$.

—.1954. "Trois traités sur les sectes bouddhiques attribués à Vasumitra, Bhavya et Vinītadeva." Journal Asiatique CCXLII: 229-56.

—. 1956. "Trois traités sur les sectes bouddhiques attribués à Vasumitra, Bhavya et Vinītadeva. 2ième Partie.” Journal Asiatique CCXLIV: 167-91.

—. 1957. "Les controverses relatives à la nature de l'arhant dans le Bouddhisme ancient." Indo-Iranian Journal 1: 241-50.

Bauer, Wolfgang. 2006. Geschichte der chinesischen Philosophie. München: C. H. Beck.

Baumann, Martin. 1995. Deutsche Buddhisten. Geschichte und Gemeinschaften. Marburg: Diagonal-Verlag.

Bayer, Achim. 2010. The Theory of Karman in the Abhidharmasamuccaya. Studia Philologica Buddhica. Monograph Series XXVI. Tokyo: The International Institute for Buddhist Studies.

Bronkhorst, Johannes. 2000. "Die buddhistische Lehre.” In Der Buddhismus I: Der indische Buddhismus und seine Verzweigungen, edited by Heinz Bechert et al., 23-213. Stuttgart: Kohlhammer.

- 2011. Buddhism in the Shadow of Brahmanism. Handbook of Oriental Studies. Section Two. South Asia. 24. Leiden: Brill.

Casirer, Ernst. 1927. Individuum und Kosmos in der Philosophie der Renaissance. Studien der Bibliothek Warburg Herausgegeben von Fritz Saxl. Leipzig and Berlin: B. G. Teubner.

Conze, Edward, trans. 1961-1964. The Large Sütra on the Perfection of Wisdom. With the divisions of the Abbidamayālamkâra. London: Luzac and Company.

Cousins, Lance S. 1991. "The 'Five Points' and the Origins of the Buddhist Schools." In The Buddhist Forum, vol. 2, edited by Tadeusz Skorupski, 27-60. London: School of Oriental and African Studies, University of London.

Cox, Collett. 1992. "Attainment through Abandonment. The Sarvāstivādin Path of Removing Defilements." In Paths to Liberation. The Màrga and its Transformations in Buddhist Thought, edited by Robert E. Buswell and Robert M. Gimello, 63-105. Studies in East-Asian Buddhism 7. Honolulu: University of Hawaii Press. 
Dessein, Bart. 2007. "The Existence of Factors in the Three Time Periods. Sarvāstivāda and Madhyamaka Buddhist Interpretations of Difference in Mode, Difference in Characteristic Marks, Difference in State, and Mutual Difference.” Acta Orientalia 60 (3): 331-50.

一. 2010. “佛十八不共法的研究: 從阿毗達摩系列轉到菩薩的秘境經 驗Chinese? Fo shiba bugongfade yanjiu: cong apidamo xilie zhuandao pusade mijing jingyan." In Kua wenhua shiyexiade dongya zongjiao chuantong, edited by Chung, Tsai-chun and Chow, Ta-hsing, 81-107. Taipei: Zhongyang yanjiuyuan zhongguo zenzhe yanjiusuo.

- 2011. "Time, Temporality, and the Characteristic Marks of the Conditioned: Sarvāstivāda and Madhyamaka Buddhist Interpretations.” Asian Philosophy 21 (4): 341-60.

Dhammajoti, Kuala Lumpur. 2009. Sarvāstivāda Abhidharma, Centre of Buddhist Studies. Hong Kong: The University of Hong Kong. Dux, Günter. 1989. Die Zeit in der Geschichte. Ibre Entwicklungslogik vom Mythos zur Weltzeit. Suhrkamp Taschenbuch Wissenschaft. Frankfurt am Main: Suhrkamp Verlag.

Eliade, Mircea. 1986. Kosmos und Geschichte. Der Mythos der ewigen Wiederkehr. Frankfurt.

Fromm, Erich, Daisetsu T. Suzuki, and Richard De Martino. 1963. Zen Buddhism and Psychoanalysis. New York: Grove Press.

Göller, Thomas, and Achim Mittag. 2008. Geschichtsdenken in Europa und China. Selbstdeutung und Deutung des Fremden in historischen Kontexten. Sankt Augustin: Academia Verlag.

Gombrich, Richard, and Gananath Obeyesekere. 1988. Buddhism Transformed: Religious Change in Sri Lanka. Princeton: Princeton University Press.

Goossaert, Vincent, and David A. Palmer. 2011. The Religious Question in Modern China. Chicago and London: The University of Chicago Press. Halbfass, Wilhelm. 2000. Karma und Wiedergeburt im indischen Denken. Kreuzlingen: Hugendubel.

Harvey, Peter. 2013. An Introduction to Buddhism. Teachings, History and Practices. Second Edition. Cambridge: Cambridge University Press. Hirakawa, Akira. 1974. Indo Bukkyō shi. 2 vols. Tokyo. Shunjūsha. Horner, Isaline B. 1954. The Collection of The Middle Length Sayings (MajjbimaNikàya). Vol. I. The First Fifty Discourses (Mülapãnñāsa). Pali Text Society. London: Luzac \& Company.

Inada, Kenneth, K. 1974. "Time and Temporality, a Buddhist Approach." Philosophy East and West 24 (2): 171-79. 
Jaini, Padmanabh S. 1992. "On the Ignorance of the Arhat." In Paths to Liberation. The Märga and its Transformations in Buddhist Thought, edited by Robert E. Buswell and Robert M. Gimello, 135-45. Studies in East-Asian Buddhism 7. Honolulu: University of Hawaii Press.

Keown, Damien, ed. 2000. Contemporary Buddhist Ethics. Richmond, Surrey: Curzon.

Kemp, Anthony. 1992. The Estrangement of the Past: A Study in the Origins of Modern Historical Consciousness. New York: Oxford University Press. Lamotte, Étienne. 1958. Histoire du bouddhisme indien: des origines à l'ère Śaka. Louvain: Institut Orientaliste.

— 1970. Le Traité de la Grande Vertu de Sagesse de Nāgārjuna (Mahāprajñāpāramitāsāâstra). Louvain: Institut de l'Institut Orientaliste. Li, Man, and Bart Dessein. 2015. "Aurelius Augustinus and Seng Zhao on 'time': An Interpretation of the Confessions and the Zhao Lun." Philosophy East and West 65 (1): 157-77.

Lopez, Donald S. 2008. Buddhism and Science. A Guide for the Perplexed. Chicago and London: The University of Chicago Press.

Maes, Claire. 2015. "Dialogues With(in) the Pāli Vinaya. A Research into the Dynamics and Dialectics of the Pāli Vinaya's Others, with a Special Focus on the Jain Other." Unpublished PhD dissertation, Ghent University.

Masuda, Jiryō. 1925. "Origin and Doctrines of Early Indian Buddhist Schools: A Translation of the Hsüan-chwang Version of Vasumitra's Treatise I-pu tsung-lun lun. Translated with Annotations." Asia Major 2: 1-78.

McMahan, David L. 2008. The Making of Buddhist Modernism. Oxford: Oxford University Press.

Nakamura, Hajime. 1996. Indian Buddhism: A Survey with Bibliographical Notes. (Reprint, Delhi: Motilal Banarsidass. 1980)

Rockhill, William W. 1884. The Life of the Buddha and the Early History of His

Order. London: Trübner.

Shizutani, Masao. 1978. Shōjō Bukkyōshi no kenkyū. Kyoto: Hyakkaen.

Sinha, Braj M. 1983. Time and Temporality in Sämkhya-Yoga and Abhidharma Buddhism. New Delhi: Munshiram Manoharlal Publishers Pvt. Ltd.

Takakusu, Junjirō, Kaigyoku Watanabe, and Gemyō Ono. 1924-1935. Taishōo shinshū daizōkyōo (Vols.1-100). Tokyo: Taishō Issaikyō Kankōkai.

T.2.99: Samyuktāgama, Za ahan jing, Guṇabhadra.

T.2.125: Ekottarāgama, Zengyi ahan jing, Saṃghadeva.

T.8.222: *Pañcavimisatisāhasrikā, Guang zan jing, Dharmarakșa.

T.25.1509: Nāgārjuna, Mahāprajñāpāramitopadeśa, Da zhidu lun, Kumārajīva.

T.49.2033: Vasumitra, Samayabhedoparacanacakra, Buzhiyi lun. Paramārtha. 
T.27.1545: 500 arhats, ['Abhidharmamahā] vibhāṣāa [śāstra], Apidamo da piposha lun, Xuanzang.

T.28.1550: Dharmaśreșthin, *Abhidharmahrdaya, Apitan xin lun, Saṃghavarman and Huiyuan.

T.28.1552: Dharmatrāta, *Samyuktābhidharmahrdaya, Za apitan xin lun. Samghavarman.

T.29.1558: Vasubandhu, Abhidharmakośa, Apidamo jushe lun, Xuanzang.

T.29.1562: Saṃhabhadra, [Abhidharma]Nyāyānusāraśāstra, Apidamo shun zhengli lun, Xuanzang.

T.50.2059: Huijiao, Gao seng zhuan.

T.55.2145: Sengyou, Chu sanzang jiji.

T.55.2154: Zhisheng, Kaiyuan shijiao lu.

Tonkinson, Carole, ed. 1965. Blue Sky Mind: Buddhism and the Beat Generation. New York: Riverhead Books.

Trenckner, Vilhelm, ed. 1888. The Majjbima-Nikāya. Vol.I. Pali Text Society.

London: Henry Frowde.

Waldschmidt, Ernst. 1980. "Central Asian Sūtra Fragments and their Relation to the Chinese Ägamas.” In The Language of the Earliest Buddhist Tradition, edited by H. Bechert, 136-74. Symposien zur Buddhismusforschung II. Göttingen: Vandenhoeck \& Ruprecht.

Walleser, Max. 1927. Die Sekten des alten Buddhismus. Heidelberg: Carl Winter's Universitätsbuchhandlung.

Wang, Bangwei. 1994. "Buddhist Nikāyas through Ancient Chinese Eyes.” In Untersuchungen zur buddhistischen Literatur, edited by Frank Bandurski, Bhikkhu Pāsādika, Michael Schmidt, and Bangwei Wang, 165-203. Sanskrit-Wörterbuch der buddhistischen Texte aus den Turfanfunden, Beiheft 5. Göttingen: Vandenhock \& Ruprecht.

Weber, Max. 1951. The Religion of China. Glencoe: The Free Press.

Willemen, Charles, trans. 1975. The Essence of Metaphysics. Abhidharmahrdaya.

Série Études et Textes 4. Brussel: Publications de l'Institut Belge des Hautes Études Bouddhiques.

Willemen, Charles, Bart Dessein, and Collett Cox. 1998. Sarvāstivāda Buddhist Scholasticism. Handbuch der Orientalistik. Zweite Abteilung. Indien. 11. Leiden: Brill.

Wogihara, Unrai, ed. 1971. Sphuṭārthābhidharmakośavyākhyā of Yaśomitra. 2 Vols. Tokyo: Sankibō Buddhist Book Store. 